\title{
PENELITIAN PENYULINGAN MINYAK PALA "SIAUW" METODE UAP BERTEKANAN DAN KARAKTERISTIK MUTU MINYAK PALA
}

\author{
NUTMEG OIL REFINING RESEARCH "SIAUW" PRESSURIZED STEAM METHOD \\ AND CHARACTERISTICS OF NUTMEG OIL
}

\author{
Fahri F. Polii \\ Balai Riset dan Standardisasi Industri Manado \\ Jalan Diponegoro No: 21-22 Manado \\ e-mail: poliifahri@yahoo.com \\ Diterima tgl 19-05-2016, Disetujui tgl 27-05-2016
}

\begin{abstract}
ABSTRAK
Tujuan penelitian ini adalah mengetahui metode penyulingan yang optimal untuk mendapatkan kualitas dan kuantitas minyak biji pala "Siauw". Penyulingan biji pala dilakukan dalam sistem tekanan uap dan proses penyulingan diawali dengan melakukan penghancuran biji pala dengan ukuran 0,5 - 1,0 cm. Selanjutnya dimasukkan ke dalam ketel penyulingan yang telah dipanaskan. Ketel uap dipanaskan hingga tekanan mencapai 1,5 bar, lalu uap dialirkan ke ketel suling. Proses penyulingan dilakukan selama 7 dan 14 jam dengan aliran tekanan uap 1 bar. Hasil pengamatan menunjukkan bahwa tekanan ketel uap 1 bar akan tercapai setelah ketel dipanaskan selama 2 jam, akan tetapi ketika uap dialirkan ke dalam ketel suling (berisi bahan biji pala), maka tekanan akan turun menjadi 0,25 bar. Pada pemanasan ketel uap selama 3 jam diperoleh tekanan 1,5 bar dan ketika uap dialirkan ke dalam ketel suling, maka tekanan turun menjadi 1 bar. Tekanan 1 bar ini akan konstan dalam proses penyulingan selama 14 jam. Hasil penelitian menunjukkan bahwa rendemen total minyak pala berkisar antara 5,63 - 6,84\%, berat jenis minyak pala berkisar antara 0,902 - 0,904 (penyulingan 7 jam) dan 0,905 - 0,918 (penyulingan 14 jam), indeks bias minyak pala 1,472 - 1,482 (7 jam) dan 1,484 - 1,490 (14 jam). Sisa penguapan memberikan hasil antara 2,2 - 2,5\% (7 jam) dan 2,6 - 2,9\% (14 jam). Uji kelarutan dalam alkohol menunjukkan perbandingan 1 bagian minyak pala dan setelah ditambahkan 3 bagian alkohol 90\% memberikan penampakan jernih baik yang disuling selama 7 jam maupun 14 jam, zat asing: negatif, bau adalah khas minyak pala dan kadar miristicin 8,56 - 8,58\% (7 jam) dan 12,58 - 12,60\% (14 jam). Hasil penelitian menyimpulkan bahwa rendemen dan sifat fisiko-kimia minyak pala secara kuantitatif dan kualitatif meningkat seiring dengan lamanya waktu penyulingan.
\end{abstract}

Kata kunci: pala, penyulingan, uap, tekanan, miristicin.

\section{ABSTRACT}

The purpose of this research is to know the optimal distillation method to get the quality and quantity of seed oil of nutmeg "Siauw". Nutmeg seeds refining is done in the system pressure and steam distillation process begins with the destruction of the nutmeg seed do with size $0.5-1.0 \mathrm{~cm}$ which further put into heated refining the kettle. Boiler is heated until pressure reaches 1.5 barr and then streamed to distillation boiler steam. The process of distillation is done for 7 and 14 hours with the flow of vapor pressure of 1 barr. The observations show that the pressure of the boiler 1 barr will be reached after heated kettle for 2 hours, but when steam was piped into the distillation kettle (contain the seeds of pala), then the pressure will drop to 0.25 barr. On the heating boiler for 3 hours obtained pressure 1.5 bar and when steam was piped into the distillation kettle, then the pressure dropped to 1 barr, where this will be 1 bar pressure constant during the refining process for 14 hours. The results showed that the total yield of nutmeg oil ranges between 5,63-6.84\%, nutmeg oil density ranging between 0,9022-0,9042 (7-hour distillation) and 0,9057-0,9181 (14-hour distillation), refractive index oils of nutmeg 1.472-1,482 (7 hours) and 1,484-1,490 (14 hours), leftover of evaporation results between 2.2-2.5\% (7 hours) and 2.6-2.9\% (14 hours). Solubility in alcohol test showed in comparison to 1 part oil of nutmeg and added 3 parts alcohol $90 \%$ gave the appearance of a good clear distilled for 7 hours or 14 hours treatment, the foreign substance: negative, the smell of nutmeg oil and is typical of the levels miristicin $8.56-8.58 \%$ (7 hours) and $12,58-12.60 \%$ (14 hours). Results of the study concluded that yield and physico-chemistry of oil of nutmeg in quantitative and qualitative increases in line with length of time refining.

Keywords: nutmeg, distillation, steam, pressure, miristicin. 


\section{PENDAHULUAN}

Tanaman pala (Myristica fragrans. Houtt) adalah tanaman asli Indonesia yang berasal dari pulau Banda. Tanaman ini dikenal sebagai tanaman rempah yang memiliki nilai ekonomi dan multiguna karena setiap bagian tanaman dapat dimanfaatkan dalam berbagai industri[18]. Minyak pala merupakan salah satu jenis minyak atsiri yang sangat diminati di pasar internasional dikarenakan penggunaannya sangat luas, seperti bahan baku dalam industri parfum, kosmetika, farmasi, makanan dan minuman, penyedap alami, selain untuk pengobatan bahkan digunakan untuk mengobati penyakit-penyakit kronis seperti kanker. Minyak atsiri yang berasal dari biji dan fuli pala banyak digunakan untuk industri obat-obatan, parfum dan kosmetik[7]. Di berbagai daerah di Provinsi Sulawesi Utara, pala menjadi komoditi unggulan yang memberikan kontribusi terhadap pertumbuhan daerah. Ada beberapa daerah di Provinsi Sulawesi Utara yang merupakan penghasil pala, salah satunya di daerah Kabupaten Minahasa Utara dan Kabupaten Kepulauan Sitaro yang merupakan sentra produksi pala[7]. Data produksi pala Propinsi Sulawesi Utara tahun 2014 10,20 ton[6], Kepulauan Sitaro luas areal tanaman pala 4.471,76 ha dan jumlah produksi 3,337,25 ton[4]. Pulau Siau yang terletak di Kabupaten Kepulauan Siau Tagulandang Biaro (Sitaro), adalah salah satu penghasil tanaman pala terbaik. Mutu pala Siau sangat khas dibandingkan dengan pala dari daerah lain. Pala Siau mempunyai ukuran paling besar dibandingkan dengan pala Indonesia lainnya. Uni Eropa memberikan
Geographical Indication bagi pala Siau dengan spesifikasi khusus. Spesifikasi tersebut membedakan pala produksi Siau dengan pala produksi daerah lain[12].

Apabila ditinjau kandungan minyak atsiri dari pala, "Banda Nutmeg" mempunyai mutu paling tinggi dan mengandung $8 \%$ minyak atsiri. "Siauw Nutmeg" mempunyai mutu hampir sama dengan "Banda Nutmeg" dengan kandungan minyak atsiri 6,5\%[9]. Biji pala mengandung fixed oilsebesar $20-40 \%$ yang tersusun dari asam miristat, trimiristin dan gliserida dari asam laurat, stearat dan palmitat[5]. Minyak pala merupakan bahan pangan yang mengandung senyawa bioaktif yang memiliki aktivitas biologis[2].

Hingga saat ini Indonesia masih mengimpor trimiristin dari luar negeri. Indonesia merupakan penghasil terbesar bahan baku biji pala di dunia. Oleh karena itu, peluang untuk mengisolasi trimiristin di dalam negeri sangatlah besar, sementara teknologi untuk produksi trimiristin cukup sederhana dan industri-industri pengguna trimiristin tersebut terus berkembang[13]. Produksi minyak pala dipengaruhi oleh banyaknya jumlah bahan baku baik dalam bentuk biji pala maupun fuli. Produksi minyak pala terkait erat dengan ketersediaan jumlah bahan baku yang didapat[19].

Metode yang dapat digunakan untuk memperoleh minyak pala umumnya adalah dengan metode distilasi uap, distilasi air, distilasi uap air dan ekstraksi dengan menggunakan pelarut. Metode penyulingan yang umum digunakan untuk memperoleh minyak pala adalah distilasi uap dengan alasan kecepatan dan 
kapasitas produksi minyak[10]. Jenis pala, agroklimat lokasi penanaman, umur panen, dan teknik penyulingan mempengaruhi kualitas minyak pala. Untuk memperoleh minyak pala yang berkualitas baik, selain dari bahan yang baik, juga sangat tergantung dari proses penyulingan yang meliputi bahan ketel, sistem pendinginan, disain ketel dan sumber pemanasan untuk penyulingan. Mengingat minyak pala memiliki nilai ekonomi tinggi dengan prospek pasar yang terbuka (pasar tidak sulit), maka perlu ditempuh langkahlangkah pengembangan secara optimal melalui peningkatan teknologi baik peralatan maupun proses produksi dan pengendalian mutu produksi juga peningkatan kemampuan para produsen minyak pala. Selain itu teknologi proses produksi yang dikembangkan dapat diaplikasikan untuk penyulingan beberapa bahan (komoditi) yang merupakan sumber minyak atsiri. Guna meningkatkan ekspor dan mengantisipasi persaingan di pasar dunia, diperlukan kegiatan riset teknologi pengolahan untuk mendukung agroindustri minyak pala dan minyak atsiri lainnya.

Tujuan penelitian ini adalah untuk mengetahui metode penyulingan yang optimal untuk mendapatkan kualitas dan kuantitas minyak biji pala "Siauw".

\section{BAHAN DAN METODE}

\section{A. Bahan-bahan}

Bahan-bahan yang digunakan dalam penelitian ini adalah biji buah pala dari Kabupaten Sitaro kecamatan Siau, minyak tanah dan bahan kimia untuk analisis mutu minyak pala
B. Alat.

Alat yang digunakan yaitu 1 (satu) set alat suling yang terdiri dari: ketel uap (boiler), ketel penyulingan, kondensor, ketel pemisah air dan minyak pala, alat penghancur biji buah pala, kompor minyak tanah (brander), neraca, gelas ukur, dan alat laboratorium untuk uji mutu minyak pala.

\section{Metode Penelitian}

1. Metode yang digunakan dalam pelaksanaan penelitian ini adalah metode deskriptif, yaitu menggambarkan keadaan hasil dari uji coba alat penyulingan di lapangan, berdasarkan fakta-fakta yang tampak untuk mengetahui unjuk kerja alat.

2. Pengamatan parameter-parameter antara lain: lama penyulingan (jam), dan jumlah minyak yang diperoleh setiap penyulingan $(\mathrm{ml})$.

3. Pengujian laboratorium terhadap contoh minyak biji pala yang dihasilkan.

\section{Tahapan Pekerjaan}

\section{Alat Penyulingan Uap}

Alat penyulingan metode uap terdiri dari beberapa bagian utama, yaitu: ketel uap, ketel penyulingan, kondensor, dan alat pemisah minyak - air.

\subsection{Ketel Uap}

Ketel uap berfungsi untuk menghasilkan uap yang akan digunakan untuk proses penyulingan. Bagian ini terbuat dari Heat Resistance Steel berdiameter 
$50 \mathrm{~cm}$ dan tinggi $120 \mathrm{~cm}$, dengan ketebalan dinding ketel uap $5 \mathrm{~mm}$. Bentuk struktur dari ketel uap adalah silinder dengan tutup berbentuk setengah bola. Ketebalan dinding ketel dirancang supaya mampu menahan beban tekanan sebesar 1 atm. Alat ini dilengkapi dengan alat pengontrol tekanan, pengontrol suhu, sistem pengaman tekanan, dan alat pengontrol tinggi rendah air dalam ketel. Di bagian atas ditempatkan tabung tempat air dengan tinggi tabung $60 \mathrm{~cm}$ dengan jarak $10 \mathrm{~cm}$ dari badan ketel uap. Ketel uap ini dihubungkan dengan bagian ketel penyulingan dengan pipa besi diameter 2 inch, dan dibungkus dengan insulasi. Ketel uap ini juga dilengkapi tungku dengan tinggi 60 $\mathrm{cm}$, diameter $76 \mathrm{~cm}$ yang terbuat dari Mild Steel dengan ketebalan 5 $\mathrm{mm}$ serta diameter lubang tungku $40 \mathrm{~cm}$. Bagian dalam disusun dengan Fire Brick. Unit pemanas terdiri dari burner besar dan selang tembaga, pompa tangan dan tabung, serta tangki minyak tanah kapasitas 30 liter.

\subsection{Ketel Penyulingan}

Ketel penyulingan berfungsi untuk menampung biji pala yang akan digunakan untuk proses penyulingan. Bagian ini terbuat dari Stainless Steel berdiameter $50 \mathrm{~cm}$ dan tinggi $120 \mathrm{~cm}$, dengan ketebalan dinding ketel penyulingan $5 \mathrm{~mm}$. Bentuk struktur dari ketel penyulingan adalah silinder dengan tutup berbentuk setengah bola. Di dalam tabung dilengkapi dengan keranjang yang dibuat dari stainless stee/ dengan ukuran tinggi $80 \mathrm{~cm}$. Jarak keranjang di atas dasar ketel $60 \mathrm{~cm}$. Disamping itu dilengkapi pipa uap bersilang di dasar ketel dengan diameter pipa uap 1 inch dilengkapi dengan lubang-lubang kecil yang berdiameter $3 \mathrm{~mm}$. Dasar ketel dilengkapi dengan sebuah kran untuk tempat mengeluarkan uap yang berkondensasi, dan juga untuk mengeluarkan air cucian. Bagian atas ketel dilengkapi leher angsa untuk mengalirkan uap dari ketel suling ke dalam kondensor, dan dipasang pada bagian tengah (bagian cembung) tutup ketel dengan ukuran pipa penghubung $10 \mathrm{~cm}$ pada jarak $15 \mathrm{~cm}$ dengan lubang ketel. Leher angsa bentuknya sedikit melengkung dan arahnya miring dari ketel langsung ke kondensor dengan kemiringan adalah $15^{\circ}$. Ukuran leher angsa tidak perlu terlalu tinggi dan diisolasi untuk mencegah kondensasi uap sebelum masuk kondensor. Bagian dinding luar dan tutup ketel penyulingan serta bagian leher angsa dilapisi dengan isolator panas.

\subsection{Kondensor}

Kondensor ini berfungsi untuk mengubah seluruh uap air dan uap minyak menjadi fase cair. Kondensor yang digunakan tipe Multitubular, berbentuk tabung 
terbuat dari Mild Steel Plate dengan diameter tabung $15 \mathrm{~cm}$, panjang tabung $160 \mathrm{~cm}$, diamater pipa 1,2 cm dengan jumlah pipa 9 buah. Kondensor ini dilengkapi aliran masuk air pendingin di bagian bawah tabung, dan aliran keluar air pendingin di bagian atas tabung. Agar proses kondensasi lebih sempurna, kondensor direndam dalam drum berisi air yang bersirkulasi.

\subsection{Alat Pemisah Air-Minyak}

Alat ini berfungsi untuk memisahkan minyak dari air suling hasil kondensasi. Untuk mencegah penguapan dan kehilangan minyak maka suhu minyak dalam alat pemisah ini dipertahankan pada suhu $20-30^{\circ} \mathrm{C}$. Bagian ini terbuat dari plat stainless steel dengan ketebalan $2 \mathrm{~mm}$. Bentuknya adalah silinder dengan diameter $20 \mathrm{~cm}$ tinggi $40 \mathrm{~cm}$. Pada bagian ini dilengkapi dengan sistem saluran pengeluaran minyak dan air yang dapat dibuka dan ditutup dengan menggunakan valve.

\subsection{Prosedur Penyulingan minyak} biji pala

Biji pala $(25 \mathrm{~kg})$ terlebih dahulu dihancurkan/dicacah menjadi ukuran 0,5 - $1 \mathrm{~cm}$. Ukuran potongan biji pala harus diusahakan seragam. Masukkan potongan-potongan biji tersebut ke dalam ketel penyulingan, Ialu penutup ketel ditutup secara rapat. Penyulingan dilakukan selama 14 jam, dan dilakukan pengamatan setiap dua jam. Minyak biji pala yang dihasilkan disimpan dalam botol kaca berwarna cokelat, kemudian ditetapkan hasilnya (rendemen).

\subsection{Pengamatan}

Kadar miristisin ditentukan menggunakan Gas Chromatografi (GC) dengan menggunakan standar miristisin. Sedangkan untuk pengujian mutu minyak biji pala yang dihasilkan dilakukan berdasarkan syarat mutu minyak pala SNI 06-2388-1998.

\section{HASIL DAN PEMBAHASAN}

\section{Alat Suling Minyak Pala}

Alat yang digunakan dalam proses penyulingan minyak atsiri (minyak dari biji pala) terdiri atas 3 (tiga) komponen utama yakni: ketel uap, ketel penyulingan dan kondensor (pendingin), serta alat pemisah minyak (florentine flask). Ketel uap, ketel suling terbuat dari pelat stainless steel dengan ketebalan $0,5 \mathrm{~mm}$ dan pada ketel uap dilengkapi dengan barometer (mengukur tekanan) skala $0-2,5$ bar dan termometer (pengukur suhu) skala $0-400$ ${ }^{\circ} \mathrm{C}$ serta pipa kaca / slang karet transparan disisi ketel untuk mengotrol air dalam ketel. Ketel uap dan ketel suling dihubungkan dengan pipa stainless stell diameter 0,5 inch berbentuk "L" dan dilengkapi dengan stop kran aliran uap dengan panjang keseluruhan pipa 3,0 m. Ketel suling dan kondensor dihubungkan dengan pipa stainless steel ukuran 0,5 inch yang juga berbentuk "L" dengan panjang 1,5 m. Ketel uap dan ketel suling terbuat dari pelat stainless steel dengan ketebalan $0,5 \mathrm{~mm}$. 
Kapasitas ketel suling yakni $50 \mathrm{~kg}$ berat bahan yang akan disuling dan dilengkapi dengan sekat berpori (berlubang) pada bagian bawah diatas pipa silang pengaliran uap. Pada awal percobaan dilakukan proses penyulingan secara bertahap untuk mengetahui waktu yang dibutuhkan pada proses pemanasan, untuk memperoleh tekanan 1 bar pada ketel uap dengan menggunakan sumber panas dari pemanas brander (bahan bakar minyak tanah). Hasil pengamatan ternyata untuk mendapatkan tekanan uap 1 bar pada ketel uap dibutuhkan waktu selama 2 jam. Akan tetapi ketika kran uap pada pipa yang menghubungkan ketel uap dan ketel penyulingan dibuka penuh ternyata tekanan pada ketel uap turun hingga 0,25 bar dan tekanan pada ketel uap tidak mengalami kenaikkan selama proses penyulingan. Pada percobaan berikutnya dilakukan pemanasan ketel uap sampai tekanan 1,5 bar dan dibutuhkan waktu selama 3 jam.
Pada saat tekanan pada ketel uap mencapai angka 1,5 bar, kran uap yang menghubungkan ketel uap dan ketel penyulingan dibuka setengah (tidak penuh). Ternyata tekanan pada ketel uap turun sampai 1 bar dan angka ini tetap bertahan selama proses penyulingan berlangsung dengan aliran panas yang tetap dan kontinudan hasil percobaan inilah yang menjadi acuan dalam proses penyulingan minyak atsiri (minyak biji pala) dalam penelitian lanjutan.

\section{Rendemen}

Pada penelitian ini telah dilakukan penyulingan biji pala dengan berat $25 \mathrm{~kg}$ setiap perlakuan dan pengamatan rendemen dilakukan pada waktu proses penyulingan berlangsung dari $0-7$ jam dan pengmatan terhadap rendemen dilanjutkan pada waktu penyulingan $7-14$ jam. Hasil pengamatan rendemen minyak biji pala tercantum pada tabel 1 berikut.

Tabel 1. Rendemen minyak biji pala

\begin{tabular}{lcrrc}
\hline \multirow{2}{*}{ No } & \multicolumn{4}{c}{ Rendemen } \\
\cline { 2 - 5 } & Perlakuan & $\mathbf{7}$ jam & $\mathbf{1 4}$ jam & Total (14 jam) \\
\hline 1. & I & 3,64 & 2,20 & 5,84 \\
2. & II & 3,48 & 2,15 & 5,63 \\
3 & III & 3,55 & 2,23 & 5,78 \\
& Rata-rata & 3,56 & 2,19 & 5,75 \\
\hline
\end{tabular}

Rendemen total minyak pala yang diperoleh dari penyulingan biji pala dengan metode penyulingan uap selama 14 jam pada tekanan 1 bar yakni antara 5,63$5,64 \%$. Pengamatan rendemen pada penyulingan selama 7 jam di bandingkan dengan 14 jam ternyata ada kenaikan dari rata-rata 3,56\% menjadi 5,75\% (Total). Dari data diatas menunjukkan semakin lama proses penyulingan, maka rendemen minyak pala semakin besar. Naiknya rendemen minyak pala dengan bertambahnya waktu penyulingan disebabkan oleh beberapa faktor yang antara lain ialah proses penetrasi tekanan uap pada biji pala tergantung pada besar kecilnya ukuran cacahan biji pala, semakin besar ukuran cacahan biji pala yang 
disuling, maka penetrasi uap kedalam biji pala semakin lama untuk menekan keluar minyak pala sehingga minyak pala akan meningkat rendemennya dengan semakin lama proses penyulingan. Faktor lain ialah jumlah bahan dalam ketel suling, semakin banyak jumlah bahan dalam ketel suling, maka semakin lama waktu yang diperlukan uap untuk masuk ke dalam bahan terutama yang ada pada bagian tengah dari tumpukan bahan biji pala sehingga peningkatan rendemen akan seiring dengan lamanya proses penyulingan. Rendemen minyak biji pala berkisar antara $2-15 \%$, maka hasil penelitian berada pada kisaran tersebut[16]. Pada penelitian ini biji pala yang digunakan adalah biji pala campuran tua dan muda dan dalam keadaan kering. Beberapa informasi yang diperoleh melalui IKM minyak atsiri (minyak biji pala) menyatakan bahwa rendemen minyak atsiri (minyak biji pala) dapat mencapai 10-12\% jika disuling dengan metoda penyulingan uap air dan lama penyulingan 20-22 jam. Namun selain lama penyulingan, ada beberapa factor yang mempengaruhi rendemen minyak pala, antara lain: umur biji pala, lama pala sejak dipetik lalu disuling, proses perajangan biji pala sebelum disuling, dan daerah asal tanaman biji pala.
Berat Jenis.

Data diatas menunjukkan semakin lama proses penyulingan, maka berat jenis minyak pala juga meningkat. Kenaikan berat jenis minyak pala selama proses penyulingan disebabkan adanya komponen/senyawa monoterpene oxygenated (terpen-o) $\left(\mathrm{C}_{10} \mathrm{H}_{16} \mathrm{O}\right)$ dalam biji pala yang mempunyai berat jenis berat atau fraksi berat. Senyawa ini akan tersuling jika waktu proses penyulingan diperpanjang. Hasil analisis komponen dengan metode GC-MS pada pemisahan komponen minyak pala, diperoleh komposisi masing-masing fraksi ringan terdiri dari senyawa monoterpene hydrocarbon. Fraksi berat terdiri dari senyawa monoterpene oxygenated dan sesquiterpene hydrocarbon. Senyawa monoterpene oxygenated (fraksi berat) ini memiliki berat molekul dan titik didih lebih tinggi dari monoterpene hydrocarbon (fraksi ringan) $\left(\mathrm{C}_{10} \mathrm{H}_{16}\right)$ sehingga total bobot molekul semakin tinggi. Akibatnya kerapatan minyak semakin tinggi, sehingga bobot jenis minyak akan semakin tinggi.

Berat jenis minyak pala hasil penelitian berkisar antara 0,902-0,904 (penyulingan 7 jam) dan $0,905-0,918$ (penyulingan 14 jam) seperti tercantum pada Tabel 2.

Tabel 2. Berat Jenis Minyak Pala

\begin{tabular}{ccccc}
\hline \multirow{2}{*}{ No. } & \multicolumn{4}{c}{ Berat jenis } \\
\cline { 2 - 5 } & Perlakuan & $\mathbf{7}$ jam & $\mathbf{1 4}$ jam & SNI 06-2388-1998 \\
\hline 1. & I & 0,903 & 0,918 & $0,876-0,919$ \\
2. & II & 0,904 & 0,905 & \\
3. & III & 0,902 & 0,907 & \\
\hline
\end{tabular}


Hasil ini jika dibandingkan dengan syarat mutu minyak pala (SNI 06-23881998) ternyata memenuhi syarat dan ini menunjukkan dalam proses penyulingan minyak pala terutama pemisahan antara air dan minyak telah dilakukan secara optimal. Hasil penelitian kandungan air dalam minyak pala dapat diminimalisasi karena salah satu indikator yang dapat dijadikan tolak ukur kenaikkan berat jenis pada minyak atsiri/minyak pala, yaitu kandungan air yang tinggi pada produk. Jika hal tersebut terjadi, dapat diduga bahwa proses pemisahan antara air dan fraksi minyak atsiri kurang sempurna.

\section{Indeks bias}

Angka indeks bias minyak biji pala hasil penelitian tercantum pada tabel 3 berikut ini.

Tabel 3. Indeks bias minyak biji pala

\begin{tabular}{ccccc}
\hline \multirow{2}{*}{ No. } & \multicolumn{4}{c}{ Indeks bias } \\
\cline { 2 - 5 } & Perlakuan & $\mathbf{7}$ jam & $\mathbf{1 4}$ jam & SNI 06-2388-1998 \\
\hline 1. & I & 1,472 & 1,490 & $1,472-1,495$ \\
2. & II & 1,473 & 1,488 & \\
3. & III & 1,482 & 1,484 & \\
\hline
\end{tabular}

Hasil Uji Indeks bias minyak pala berada pada kisaran 1,472 - 1,482 ( 7 jam) dan 1,484-1490 (14 jam). Hasil uji indeks bias hasil penelitian apabila dibandingkan dengan Standar Nasional Indonesia (SNI) minyak pala ternyata memenuhi syarat. Salah satu parameter yang dapat dijadikan ukuran atau pedoman untuk mengetahui kemurnian minyak pala adalah dengan menguji indeks bias minyak pala dan dibandingkan dengan persyaratan pada standar minyak pala. Jika indeks bias minyak pala tidak memenuhi persyaratan yang berlaku, dapat diduga bahwa minyak pala dalam proses penyulingan kurang optimal atau adanya komponen bukan minyak pala yang tercampur. Indeks bias dalam minyak pala sangat dipengaruhi banyaknya senyawa baik fraksi berat maupun ringan dalam minyak pala. Jika senyawa fraksi berat banyak terkandung dalam minyak pala, maka semakin sulit sinar dibiaskan dalam medium minyak pala, dengan sendirinya indeks bias semakin tinggi. Hasil analisis sifat fisikokimia pada pemisahan komponen minyak pala menunjukkan fraksi berat mempunyai nilai viskositas, berat jenis dan indeks bias yang lebih besar dari fraksi ringan[1].

\section{Sisa penguapan}

Pengamatan sisa penguapan terhadap minyak biji pala hasil penelitian dapat dilihat pada Tabel 4. 
Tabel 4. Sisa penguapan minyak biji pala

\begin{tabular}{ccrcc}
\hline \multirow{2}{*}{ No. } & \multicolumn{4}{c}{ Sisa penguapan (\%) } \\
\cline { 2 - 5 } & Perlakuan & $\mathbf{7}$ jam & $\mathbf{1 4}$ jam & SNI 06-2388-1998 \\
\hline 1. & I & 2,5 & 2,9 & maks. 3,0 \\
2. & II & 2,4 & 2,7 & \\
3. & III & 2.2 & 2,6 & \\
\hline
\end{tabular}

Minyak biji pala setelah dilakukan uji sisa penguapan memberikan hasil antara 2,2-2,5\% (7 jam) dan 2,6-2,9\% (14 jam). Kadar sisa penguapan terendah diperoleh pada penyulingan selama 7 jam dan tertinggi pada penyulingan selama 14 jam. Dari data diatas menunjukkan bahwa semakin lama proses penyulingan, makin besar kadar sisa penguapan dalam minyak biji pala. Sisa penguapan pada minyak biji pala adalah komponen-komponen yang tidak menguap pada pemanasan diatas $100^{\circ} \mathrm{C}$. Diduga semakin lama proses penyulingan semakin banyak komponenkomponen yang tidak menguap pada suhu $100{ }^{\circ} \mathrm{C}$ yang ada dalam minyak biji pala ikut tersuling, seperti lemak pala dan lain-lain. Tingginya sisa penguapan pada minyak pala penyulingan 14 jam menunjukkan banyaknya bahan non volatil yang tertinggal selama proses penguapan. Minyak kardamon dan minyak cengkeh komersial hasil destilasi dengan uap berbeda dengan minyak hasil ekstraksi $\mathrm{CO}_{2}$ yang memiliki jumlah komponen non volatil yang tinggi dan bahan pewarna (coloring materials) [9]. Mayoritas komponen non volatil ini adalah lemak berupa asam lemak tidak jenuh dalam jumlah yang banyak. Minyak citrus yang diekstraksi dengan coldpressing menunjukkan besarnya sisa penguapan (2-15\%). Hal ini disebabkan karena minyak citrus tersebut berisi bahanbahan non volatil dalam jumlah yang besar antara lain koumarin, psoralens, dan flavon polymethoxylat yang memiliki sifat antioksidatif[15].

\section{Kelarutan dalam alkohol}

Hasil uji kelarutan dalam alkohol minyak biji pala tercantum pada tabel 5 .

Tabel 5. Kelarutan dalam alkohol minyak biji pala

\begin{tabular}{ccccc}
\hline \multirow{2}{*}{ No. } & \multicolumn{4}{c}{ Kelarutan dalam alkohol } \\
\cline { 2 - 5 } & Perlakuan & $\mathbf{7}$ jam & $\mathbf{1 4}$ jam & SNI 06-2388-1998 \\
\hline 1. & I & $1: 3$ jernih & $1: 3$ jernih & $1: 3$ jernih \\
2. & II & $1: 3$ jernih & $1: 3$ jernih & seterusnya jernih \\
3. & III & $1 ; 3$ jernih & $1: 3$ jernih & \\
\hline
\end{tabular}

Minyak biji pala hasil penelitian setelah dilakukan uji kelarutan dalam alkohol ternyata pada perbandingan 1 bagian minyak pala dan setelah ditambahkan 3 bagian alkohol 90\% memberikan penampakan jernih baik yang disuling selama 7 jam maupun 14 jam. Salah satu indikator minyak atsiri (minyak pala) tidak murni atau telah tercampur dengan minyak mineral yakni pada 
pengujian kelarutan dalam alkohol akan memberikan warna keruh. Hasil penelitian menunjukkan bahwa tidak ada komponen lain yang mencemari minyak pala. Hasil ini memenuhi persyaratan Standar Nasional Indonesia Minyak Biji Pala No. 06-23881998.

Nilai kelarutan minyak pala dalam etanol merupakan indikasi dari kemampuan minyak pala melarut sempurna dalam alkohol. Semakin besar jumlah etanol berkonsentrasi tertentu yang dibutuhkan untuk melarutkan minyak pala, maka semakin sukar minyak pala larut dalam etanol. Umumnya minyak atsiri (minyak pala) yang mengandung persenyawaan oxygenated terpene (terpen-o) lebih mudah larut daripada yang mengandung terpene. Dua senyawa akan saling melarut sempurna pada perbandingan dan konsentrasi tertentu jika polaritasnya sama. Minyak pala hasil penelitian ini diduga banyak mengandung senyawa mono terpene oxygenated (terpen-o) yang mudah larut dalam alkohol dibandingkan senyawa monoterpene dan sesquiterpene hydrocarbon. Semakin banyak kandungan senyawa oxygenated monoterpene(terpeno) dalam minyak maka semakin tinggi kelarutan dalam alkohol dibandingkan senyawa terpen[9].

Zat Asing (Lemak, alkohol tambahan, minyak pelikan dan minyak terpentin)

Hasil uji zat/bahan asing terhadap minyak biji pala menunjukkan tidak teridentifikasi adanya lemak, alkohol tambahan, minyak pelikan maupun minyak terpentin. Uji ini dilakukan sebagai acuan untuk dibandingkan dengan persyaratan mutu yang tercantum dalam Standar Nasional Indonesia minyak biji pala No. 062388-1988.

\section{Bau}

Uji bau dilakukan sebagai uji mutu rekomendasi yang tertuang dalam persyaratan mutu minyak biji pala. Adapun hasil uji bau minyak biji pala hasil penelitian tercantum pada tabel 6 .

Tabel 6. Bau minyak biji pala

\begin{tabular}{|c|c|c|c|c|}
\hline \multirow{2}{*}{ No. } & \multirow{2}{*}{ Perlakuan } & \multicolumn{2}{|c|}{ Bau } & \multirow{2}{*}{ SNI 06-2388-1998 } \\
\hline & & 7 jam & 14 jam & \\
\hline 1. & $\mathrm{I}$ & khas minyak pala & Khas minyak pala & Segar, \\
\hline 2. & II & khas minyak pala & Khas minyak pala & khas minyak pala \\
\hline 3. & III & khas minyak pala & Khas minyak pala & \\
\hline
\end{tabular}

Uji bau terhadap minyak biji pala hasil penelitian menunjukan bahwa baik biji pala yang disuling selama 7 jam maupun penyulingan selama 14 jam berbau segar dan khas minyak pala. Hasil ini sesuai dengan yang dipersyaratkan sebagai uji rekomendasi dalam SNI No. 06-23881998, standar mutu minyak pala
Indonesia.Hal ini juga menandakan bahwa peralatan yang digunakan dalam proses penyulingan tidak mempengaruhi sifat organoleptic minyak yang disuling sebab alat terbuat dari stainless steel dan juga proses penyulingan secara uap bertekanan menghindari terjadinya bahan menjadi hanggus selama penyulingan karena bahan 
biji pala tidak bersentuhan langsung dengan panas dari api pembakaran (ketel penyulingan terpisah dari ketel uap).

\section{Miristicin.}

Kadar miristicin minyak pala hasil penelitian tercantum pada table 7 .

Kadar miristisin dalam minyak pala merupakan salah satu parameter yang dijadikan acuan mutu minyak pala dan dalam perdagangan internasional menjadi acuan dalam penentuan harga minyak pala. Kadar miristisin minyak pala ternyata memberikan hasil yang berbeda jika ditinjau dari lama waktu penyulingan.

Tabel 7. Kadar Miristisin minyak biji pala

\begin{tabular}{cccc}
\hline \multirow{2}{*}{ No. } & Perlakuan & \multicolumn{2}{c}{ Miristicin (\%) } \\
\cline { 3 - 4 } 1. & $\mathbf{7}$ jam & $\mathbf{1 4}$ jam \\
\cline { 3 - 4 } 1. & I & 8,56 & 12,60 \\
2. & II & 8,58 & 12,58 \\
3. & III & 8,56 & 12,60 \\
\hline
\end{tabular}

Pada waktu penyulingan selama $0-7$ jam kadar miristisin rendah yakni 8,56-8,58\%, sedangkan pada penyulingan antara 7-14 jam kandungan miristisin dalam minyak pala hasil sulingan meningkat menjadi $12,58-12,60 \%$. Hal ini memberikan petunjuk bahwa pada awal penyulingan maka komponen miristisin belum banyak yang terbawa oleh uap air, akan tetapi semakin lama waktu penyulingan, maka semakin banyak miristisin yang terbawa oleh uap air dan dengan sendirinya meningkatkan kadar miristisin dalam minyak biji pala hasil sulingan dengan metoda penyulingan uap air. Masyitah (2006) telah mengisolasi trimiristin dari sisapenyulingan biji pala,hasilnya menunjukkan rendemen trimiristin sebesar $21,60 \%$ dengan kemurnian89,86\%.Ma'mun (2013) mengisolasi trimiristin dari minyak pala Papua menghasilkan rendemen sebesar $79,55 \%$ dengan kemurnian 99,20\%. Kandungan miristisin sangattergantung pada usia pala. Pada usia muda,kandungan miristisin semakin besar danmakin berkurang pada pala yang telah tua. Miristisin adalah obat psikoaktif, bertindaksebagai antikolinergik, dan merupakan prekursor tradisional untuk psychedelic dan empathogenic (Syarifuddin Idrus, Marni Kaimudin, Risna F. Torry, dan Reynaldo Biantoro, 2014)

\section{KESIMPULAN}

Rendemen minyak atsiri (minyak biji pala) yang disuling dengan metoda penyulingan uap air pada tekanan 1 atmosfir dan lama penyulingan 14 jam adalah rata-rata $5,77 \%$.

Rendemen maupun kandungan fisiko-kimia minyak pala akan meningkat seiring dengan lamanya proses penyulingan

Minyak atsiri hasil penyulingan biji pala mempunyai berat jenis, indeks bias, kelarutan dalam etanol, sisa penguap, zat asing dan bau memenuhi persyaratan Standar Nasional Minyak Biji Pala 
Kadar miristisin minyak biji pala dipengaruhi oleh lama waktu penyulingan dimana pada waktu penyulingan antara 0-7 jam kadar miristisin $8,56 \%$ dan antara $7-14$ jam kadar miristisin $12,60 \%$.

\section{DAFTAR PUSTAKA}

1. Abimanyu $\mathrm{H}$, Sulaswaty, Wuryaningsih dan Agustian E. Penggunaan Distilasi Fraksionasi Vakum Untuk Pemisahan Komponen Minyak Pala. Pusat Penelitian Kimia-Lembaga IImu Pengetahuan Indonesia LIPI) Kawasan PUSPIPTEK Serpong, Tangerang. 2004

2. Aisyah $Y$, Safriani $N$, Muzaifa $M$, Fakhrurrazi. Optimasi Proses Emulsifikasi Minyak Pala (Myristica fragrans Houtt). Prosiding Seminar Agroindustri dan Lokakarya Nasional FKPT-TPI. Program Studi TIP-UTM, 2-3 September 2015. 2015.

3. Asyik N, Astuti I. Karakterisasi mutu minyak pala (nutmeg oil) Indonesia sebagai bahan baku industri flavor. Jurnal Agriplus. 2010;20(2):146-54.

4. Badan Pusat Statistik Provinsi Sulawesi Utara. Luas Dan Produksi Tanaman Pala. Manado. 2014.

5. Devi P. The compound maceligan isolated from Myristica fragrans. European Journal of Pharmacy Research. 2009;2(11):166975.

6. Dinas Perkebunan Provinsi Sulawesi Utara. Data Produksi Pala. Manado. 2015.

7. Elyana. Pengaruh Waktu Destilasi Terhadap Kadar Minyak Atsiri Pada Biji Pala. Skripsi. Fakultas Matematika dan IImu Pengetahuan Alam Universitas Sumatera Utara. Medan. 2014

8. Gopalakrishnan N. Studies on the storage quality of CO2-extracted cardamom and clove bud oils. Journal of agricultural and food chemistry. 1994;42(3):796-8.

9. Guenther E. Minyak atsiri jilid I. Jakarta: Penerbit Universitas Indonesia. 1987.

10. Sara $E$, llmawati $H$, Hidayati $N$. Penyulingan minyak biji pala: pengaruh ukuran bahan, waktu dan tekanan penyulingan terhadap kualitas dan rendemen minyak. Simposium Nasional RAPI XIV-2015FT UMS. 2015

11. Idrus S, Kaimudin M, Torry RF, Biantoro R. Isolasi trimiristin minyak pala banda serta pemanfaatannya sebagai bahan aktif sabun. Journal of Industrial Research (Jurnal Riset Industri). 2015 Apr 1;8(1).

12. Perindustrian K. Berita Industri: Industri Manufaktur Ekspansi Rp96, 5 T. Retrieved Februari. 2014;10:2015.

13. A'MUN MA. Karakteristik minyak dan isolasi trimiristin biji pala papua (Myristica argentea). Jurnal Penelitian Tanaman Industri. 2013 Jun 1;19(2):72-7.

14. Masyithah Z. Pengaruh Volume dan Konsentrasi Pelarut pada Isolasi Trimiristin dari Limbah Buah Pala. Jurnal Teknologi Proses. Universitas Sumatera Utara, Medan. 2006 5(1):64-67.

15. Njoroge SM, Ukeda $H$, Sawamura $M$. Changes of the volatile profile and artifact formation in Daidai (Citrus aurantium) coldpressed peel oil on storage. Journal of agricultural and food chemistry. $2003 \mathrm{Jul}$ 2;51(14):4029-35.

16. Nurdjannah N. Teknologi Pengolahan Pala. Balai Besar Penelitian dan Pengembangan Pasca Panen Pertanian, Balai Penelitian dan Pengembangan Pertanian Departemen Pertanian, Bogor. 2007.

17. Pangalima S, Pakasi CB, Benu NM. Analisis Sub Sektor Perkebunan Pala di Provinsi Sulawesi Utara. AGRISOSIOEKONOMI. 2016 Nov 2;12(1):6776.

18. Sipahelut SG. Karakteristik kimia minyak daging buah pala (Myristica fragrans Houtt) melalui beberapa cara pengeringan dan distilasi. Jurnal Agroforestri VII. 2012. Nomor 1 Maret 2012

19. Yunianto NS, Setiadi A. Analisis Faktorfaktor Produksi yang Mempengaruhi Keuntungan Agroindustri Kecil Penyulingan Minyak Pala dan Dampaknya pada Pendapatan Asli Daerah Kabupaten Bogor. Agromedia. 2013 Vol. 31 No. 1 Maret 2013 